https://doi.org/10.5800/GT-2017-8-3-0255

\title{
GEOCHEMICAL CHARACTERISTICS OF TIANMENSHAN COMPOSITE PLUTON, SOUTH CHINA
}

\author{
Yanjiao Chen, Bin Chen, Xiaoxia Duan
}

School of Resources and Environment Engineering, Hefei University of Technology, Hefei 230009, China

For citation: Chen $Y$., Chen B., Duan X., 2017. Geochemical characteristics of Tianmenshan composite pluton, South China. Geodynamics \& Tectonophysics 8 (3), 433-434. doi:10.5800/GT-2017-8-3-0255.

The southern Jiangxi province is located at east Nanling range, which is an important $\mathrm{W}$-Sn metallogenic province of China. The Early Yanshanian Tianmenshan is composed of the main-phase porphyritic biotite granite and the highly differentiated fine-gained biotite granite, intruding in the Lower Cambrian Niujiaohe Formation. The main-phase granite and the late-stage highly differentiated granite emplaced at 152-158 Ma and 152-151 Ma, respectively. The later was in the center of the pluton as a ovalize shape, with a transitional contact with the main-phase granite.

The main-phase granite is composed of quartz (35-40 \%), K-feldspar (35-40\%), plagioclase (20$30 \%$ ) and minor biotite (5-10\%). Myrmekitic texture only appears in the fine-gained porphyritic granite of the main-phase. The highly differentiated granite is composed of quartz (40-45\%), K-feldspar (25-35\%) and plagioclase (25-30\%) and biotite (5-10\%). Myrmekitic texture occurs in most thin sections.

The Tianmenshan granite has high content of $\mathrm{SiO}_{2}$, with average value of $76.02 \%$. The highly differentiated granite is depleted in $\mathrm{CaO}, \mathrm{MgO}, \mathrm{FeO}$ and $\mathrm{P}_{2} \mathrm{O}_{5}$. The trace element is depleted $\mathrm{Sr}, \mathrm{Eu}, \mathrm{Ti}$, and enriched in $\mathrm{Li}, \mathrm{Be}, \mathrm{Y}$, with $\mathrm{Sr} / \mathrm{Y}$ ratio close to zero. The main-phase granite is peraluminous with A/CNK from 1.11 to 1.13. While the highly differentiated granite is weak peraluminous. The low $\mathrm{CaO}$ and $\mathrm{Sr}$ contents suggest a residue of plagioclase in the source. In the normalized patterns of REE, the main-phase shows a smooth functions of ionic radius and atomic number, except the Eu, and the 
$\mathrm{La} / \mathrm{Yb}$ ratio is $4.8-12.5$. The highly differentiated granites are very different from the main-phase and are characterized by non-CHARAC trace element behaviour, eg., non-chondritic $\mathrm{Y} / \mathrm{Ho}, \mathrm{Zr} / \mathrm{Hf}$ ratios, and the lanthanide tetrad effect with $\mathrm{TE}_{1,3}=0.97-1.16$.

The main-phase granite shows features of normal granites, while the highly differentiated granite is characterized by the REE tetrad effect and non-CHARAC behaviors, eg., non-chondritic $\mathrm{Zr} / \mathrm{Hf}$ and $\mathrm{Y} / \mathrm{Ho}$ ratios.
Traditionally, the REE tetrad effect and non-CHARAC behaviors are thought to be the result of the high evolution of the magma or the intense interaction between the melt and fluid. The lack of REE tetrad effect in the main-phase granite, which also has high differentiation characteristics with the late-stage granite, argues that the REE tetrad effect may be caused by the intense interaction of the melts and fluids. 